\title{
Book Review Department
}

SOCIAL REALITIES AND THE SOCIAL WORK RESPONSE: THE ROLE OF SCHOOLS OF SOCIAL WORK, Proceedings of the XVIIlth International Congress of schools of Social Work. New York: Inter-. national Association of Schools of Social Work, 1977.

I often tell my students to read a book for "what turns you on or what applications you can make of the content". The reader will find much in this silim volume (173 pp.) that is both provocative and useful. Divided into three sections - plenary papers, regional reports, and summaries of the issues discussed at the 1976 meetings in San Juan, the book opens with an analysis of international social realities by Eugene Pusic that is guaranteed to be disquieting. The former president of the International Conference on Social Welfare and the Dean of the Faculty of Law at the University of Zagreb discusses the classic dilemma; building a professional and technical competence based on scientific knowledge while maintaining a day to day commitment to compassion and tolerance.

Against the background of world patterns of inequality and the naked exploitation of millions and of impending disaster as the world sits on a stockpile of 3000 tons of plutonium, itself the product of scientific knowledge, he cautions us not to build social work education on a one-sided commitment to scientific objectivity. Today's social realifies call for taking sides, making moral choices, committing ourselves to acts of courage. He concludes with a veiled criticism of our welfare instifutions. Pusic has played the role of social critic, agent provacateur, visionary and prophet exceedingly well. But he leaves the reader unsatisfied. While he has "turned us on", I'm not certain that what he has given us would be useful without the paper that follows.

Agreeing with Pusic's commitment to risk faking and morale choice, Jona Rosenfeld, in the second plenary paper, approaches his rask from a different perspective. Director of the Paul Baerwald School of Social Work of the Hebrew University in Israel, Prof. Rosenfeld uses his unique vaniage point in an examination of the universal and the particular in social work educction. What is universal is a com. mitment to the humanization of sociely and the fostering of the well being and development of individuals in those societies. But these very concepts provide a challenge to social work education. The interpretation of these values differs in each society and often within a particular society. For this reason, he points out, it is not enough to teach the knowledge and skill needed to intervene according to professionally sound principles, one must also free the intervenor to "invent interventions", to innovate in response to particular sircumstances.

In his comments on Rosenfeld's paper Vukani Nyrienda Zambia cautions against too easy acceptance of a universal base for social work education, pointing out that much of it may be the left-overs of the technical assistance proferred to developing nations following the era of colonialism. Lila deMateo Alonso of Venezuela levels the charge that social work may itself lead to a new form of exploitation by supporting existing power structures and the economic interests of ruling closses, using her comments to espouse a radical position, more than as an opportunity to comment on Rosenfeld's paper.

Eight regional reports follow. One might expect these to be rather bland considering the enormous amounts of material to be covered. Not so. Mukhtor 1. M. Agouba, formerly executive director of the Association for Social Work Education in Africa, provides the reader with a great number of examples of innorations in educational practice in his region. He describes : student initiated elient involvement in the Sudan; the research emphasis in Kenya, Ethiopia, Uganda, Mauritius, Ghana; training courses tor volunteers in Nigeria and Tanzania; and other new efforts related to rural development policy, populafion planning elsewhere.

The reports of other locales are no less comprehensive. Of interest is the remarkable range of innovations peculiar to some regions and sub-regions : community education in Asia; extra-mural training for new workers in the Carribean; the invalvement of Puerto Rican students in political action. There seems to be a new conversion of interests in other regions. These include: a growing concern with the impact of professianalization on client-orientation expressed in some European countries; attempts to reconceplualize social work and social work education in both economic and socio-political terms in South America a comparable radicalization or anti-professionalism being expressed in Canada; a response by social work education in the United States to the challenges posed by increasingly vocal groups - feminists, racial minorities, and others who consider themselves disenfranchised or discriminated against. If is my impression that these reports show the developed nation's converging in their agreement on what is 
universal in social work; while developing nations are somewhat more prone to seek their own patterns in response to particular situations. Despite, the diversities expressed, a remarkable consensus seems, to prevail.

It is a consensus that may draw less from a fully agreed upon knowledge base and fechnology (what. we have come to recognize as the hall marks of a profession) and more from a moral commitment to deal with the consequences of some of the social realities Pusic mentions: The document attests to the fact that social work and social work education does promole the invention of interveritions adyocated by Fosenfeld. But the efforts in this direction may be too fimid, as 'some educators play it safe. "For those who are willing to take risks, there will be much in this volume that furns them on, and not a little that they might find applicable in their work.

Armand Lauffer, Ph.D.

Prof. of Social Work

U.S.A. University of Michigan

Armand Lauffer, Professor of Social Work at the University of Michigan, is spending the 1977-78 and 78-79 academic years of the Hebrew University. He is the author of numerous volumes on community organization, social planning, continuing education and gaming as an intervention technique.

CROSS-CULTURAL LEARNING AND SELF-GROWTH," Mildred Sikkema and Agnes M. Niyekawa-Howard. International Association of Schools of Social Work and the University of Hawail School of Social Work, 1977. Pp. xii +121 . US\$6.00.

This book compares and assesses three types of cross-cuitural learning programmes undertaken by students of the Scthool of Social Work of the University of Hawaii, first in Guom and later in Molokai lar essentially rural island in the Hawaiian groupl and Honolulu. One of the significant objectives of the whole project was to give an opporfunity for divergent thinking in an educational process of culturelearning wherein the students were to risk themselves, to take chances, and be prepared for unexpected and possibly' negative outcomes. In this project, of which the three programmes were a part, students learned how to learn onother culiure, to develop a sensitivity to cues in any cullure with which they came into confact, rather than to learn the specifics of a culture. This meant functioning for a time in an uncomfortable and ambiguous situation where a student's own cultural framework was of no use, and "culture shock" had to be lived through until a new framework was structured by the student himself. The authors considered that learning to tolerate and cope with ambiguities until one knows more about the situation would have a generalizable effect, both on learning the new culture and on the personal development, of the learner. The underlying assumption of the project was that professional edueation for social work should stimulate "an active understending of culfural differences and encourage graduates to deal with these cultural differences as they now deal with individual differences". The project, in sum, was to prepare Social Workers who could function effectively in any culture or sub-culture, inside or outside their own, and to help them to become more flexible and creative through experiential learning. This book is very practical and has international value.

The core of culture leorning, in the view of the authors, is experiential learning. However, the experience of the project was deliberately designed to be unstructured. Students had no definite role to play. in the foreign culture, they were not sent to provide a social service, or to carry out research. Minimum training specific to the culture in which they were to be immersed was given. Indeed, a built-in ambiguity in the new culture characterized the project. The siudents had only the humble role of learner, "with everybody in the culture a potential teacher from whom he could learn".

The project provided for both cognitive and experiential learning opportunities. A pre-training seminar held at the home School of Social Work emphasized cognitive, learning when a student was helped to become consciously aware of his own culfure in order to see it in relation to another culfure or sub-culture. The field experience in another culture offered exposure sufficient to disorganize cusfomary comfortable values, patterns of thought, and behaviour. Following the field experience an opportunity was given to provide for infegration and a conscious formulation. and use of the learning at an integration seminar. Chapters 2 and 3 of the book explain the theoretical bases for, and the methodology of the project. Chapters 4 and 5 give faseinating defails of the 